\title{
АНАЛИЗ ОБЪЕДИНЕНИЯ СЕЛЬСКИХ ПОСЕЛЕНИЙ ВОЛОСОВСКОГО МУНИЦИПАЛЬНОГО РАЙОНА
}

\author{
(C) 2021 Бородина Лидия Викторовна \\ начальник сектора внутреннего финансового контроля \\ Администрация муниципального образования Волосовский муниципальный район, Россия, Волосово \\ E-mail: lidaborodina@gmail.com \\ (C) 2021 Кузнецова Марина Николаевна \\ кандидат экономических наук, доцент кафедры менеджмента \\ Государственный институт экономики, финансов, права и технологий, Россия, Гатчина \\ E-mail: dvinskih_marina@mail.ru

\section{(c) 2021 Якимчук Наталья Николаевна} \\ кандидат политических наук, доцент высшей инженерно-экономической школы \\ Санкт-Петербургский политехнический университет Петра Великого, Россия, Санкт-Петербург \\ E-mail: yakimchuk777@bk.ru
}

В статье исследованы результаты объединения сельских поселений Волосовского муниципального района Ленинградской области. Авторы проводят анализ расходов на содержание органов местного самоуправления, изучают штатную численность и доходы местных бюджетов до и после преобразования. Представлены основные преимущества и недостатки укрупнения сельских поселений.

Ключевые слова: местное самоуправление, территориальная организация, объединение сельских поселений, преобразование муниципальных образований.

В современных условиях наблюдаются серьезные изменения в территориальной организации местного самоуправления в России. Основные тенденции связаны с сокращением количества муниципальных образований в результате их преобразования. Процедуры преобразования приводят к укрупнению муниципальных образований как за счёт объединения (в большинстве своем сельских поселений), так и в результате изменения правового статуса территорий муниципалитетов. После редакции понятия городского округа в Федеральном законе от 06.10.2003 N131-Ф3 «Об общих принципах организации местного самоуправления в Российской Федерации» [2] в 2017 и 2019 годах и введения в 2019 году нового вида муниципального образования - муниципальный округ в ряде регионов начался массовый процесс отказа от поселенческого уровня местного самоуправления. В 2020 году в контексте внесенных поправок в п.1 ст.132 Конституции Российской Федерации в основном законе страны исчезает понятие поселения как вида муниципального образования [1].

В рамках современной территориальной реформы института местного самоуправления важно понять, насколько обоснованными, как с точки зрения экономической, так и социальной эффективности являются решения федеральных и региональных органов государственного управления, которые являются законодателями и определяют вектор развития самого близкого к населению уровня единой системы публичной власти в РФ.

Целью настоящей статьи является анализ результатов объединения сельских поселений в Волосовском муниципальном районе Ленинградской области для определения положительных и отрицательных сторон данных преобразований.

При проведении исследования использовался метод контент-анализа отчётных аналитических документов, размещённых на официальных сайтах администраций Ленинградской области, Волосовского муниципального района и поселений района [5-12]. Систематизация полученных данных проведена авторами в сводных таблицах настоящей статьи.

Территориальная организация Волосовского муниципального района сложилась исторически, с учетом федерального и областного законодательства. 
В 1994 году сформировались территории волостей в границах бывших сельских советов. Всего было создано 16 волостей, в том числе 2 поселка городского типа - Волосово и Кикерино. В 1999 году поселок городского типа Волосово получил статус города.

В 2002 году было принято решение об образовании Кикеринского административного округа путем объединения Губаницкой и Калитинской волостей, а также поселка Кикерино. В результате увеличились расходы бюджета на возмещение расходов автопредприятию по пассажирским перевозкам, налоговые сборы в бюджет сократились, руководство не смогло уделять внимание такой большой территории и население жаловалось на отдаленность от местной власти, сложность решения проблем.

В 2004 году поселок городского типа Кикерино сменил свой статус на «поселок».

С момента вступления в силу ФЗ «Об общих принципах организации местного самоуправления в Российской Федерации» от 06.10.2003 года
№ 131, в 2006 году на территории Волосовского муниципального района установлены границы муниципальных образований: 15 сельских и 1 городское поселения (рис. 1), зарегистрированы их Уставы, в каждом были приняты геральдические символы (герб и флаг), а также разработаны генеральные планы застройки территорий поселений [6].

В состав Волосовского муниципального района входило 16 поселений (из них 1 городское (ГП) - Волосовское), в том числе 7 сельских поселений (СП) с численностью населения от 1,3 до 2 тыс. человек (Беседское, Рабитицкое, Каложицкое, Клопицкое, Сабское, Терпилицкое, Зимитицкое), 2 сельских поселения с численностью от 2 до 2,5 тыс. человек (Кикеринское и Сельцовское). Показатели социально-экономического развития поселений Волосовского района позволяют сделать вывод о том, что наиболее развитыми в сфере экономики являются 3 поселения района - Волосовское ГП, Рабитицкое СП и Кикеринское СП.

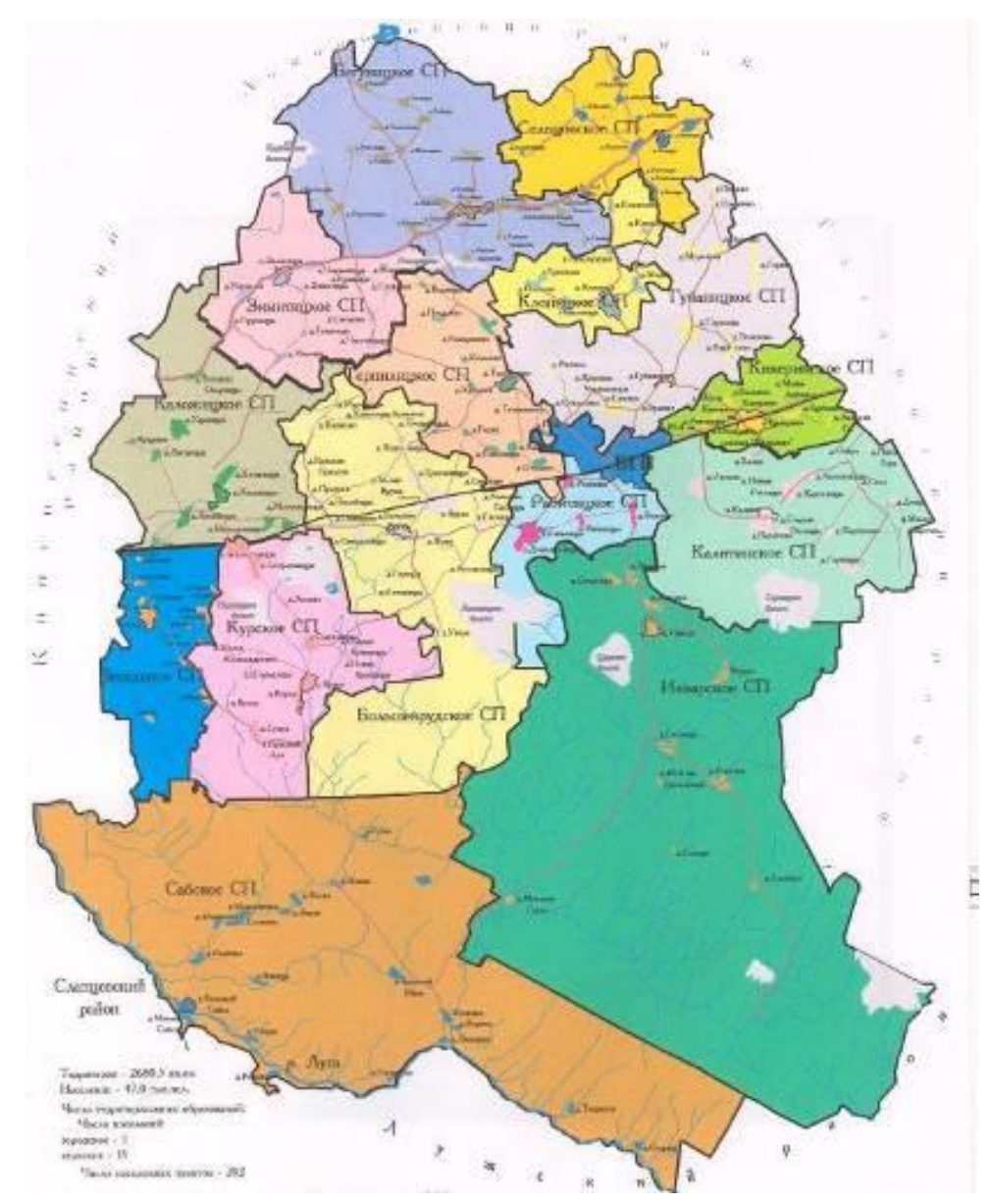

Рисунок 1. Муниципальные образования Волосовского района до 01.01.2020 года [6] 
В 2013 году Правительство Ленинградской области предложило реформирование системы территориальной организации местного самоуправления на территории Волосовского муниципального района. Предложенные изменения были обусловлены большим количеством поселений с численностью населения менее 2500 человек, слабым экономическим потенциалом, недостаточной бюджетной обеспеченностью поселений, нехваткой высококвалифицированных кадров в системе муниципальной службы поселений. Для решения вышеуказанных проблем было предложено провести укрупнение муниципальных образований путем присоединения дотационных сельских поселений к поселению с более высоким уровнем социальноэкономического развития с работающими промышленными и сельскохозяйственными предприятиями.

Комитетом по экономическому развитию и инвестиционной деятельности Ленинградской области были предложены варианты преобразования муниципальных образований Волосовского муниципального района. С точки зрения экономической целесообразности, учитывая территориальное расположение поселений
Волосовского района, рассматривался вопрос об образовании 3 административных округов путем объединения наиболее экономически развитых поселений, где имеются стабильно работающие предприятия - Волосовского ГП, Кикеринского СП и Рабитицкого ГП. Предлагалось 2 варианта объединения поселений (рис. 2).

Объединение поселений, бюджета, общего имущества, а также одного органа местного самоуправления позволит более рационально использовать бюджетные средства, их можно будет направить на решение вопросов местного самоуправления, а не содержание управленческого аппарата.

Но предлагаемые объединения муниципальных образований Волосовского муниципального района не были реализованы. Однако некоторые изменения территориальной организации местного самоуправления на территории района все же произошли. На основании Устава Волосовского муниципального района Ленинградской области Администрация Волосовского муниципального района с 2013 года реализует полномочия по решению вопросов местного значения муниципального образования Волосовское городское поселение. Исполняет полномочия Ко-

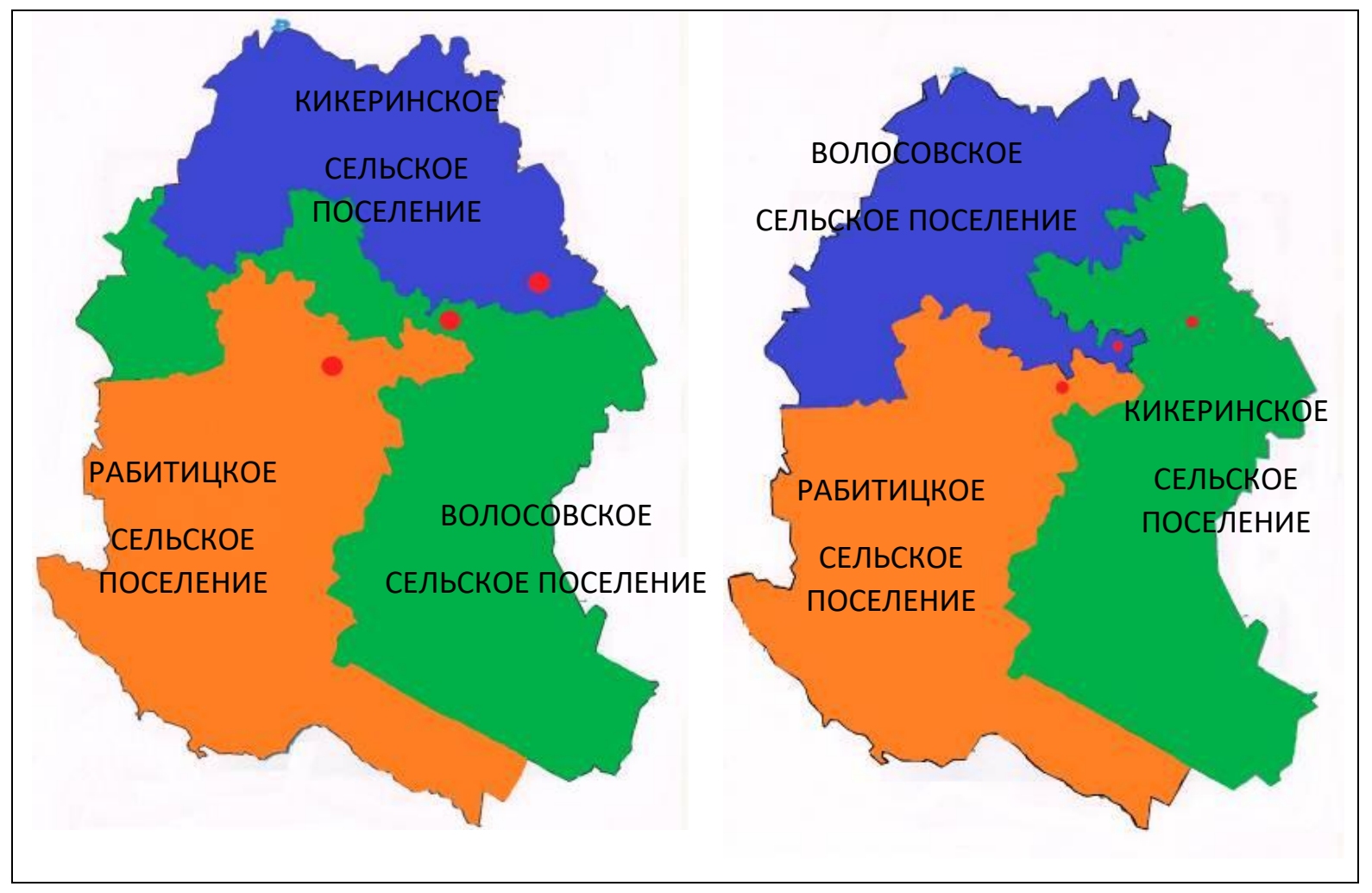

Рисунок 2. Варианты объединения муниципальных образований Волосовского муниципального района [составлен авторами] 
митет по городскому хозяйству Администрации Волосовского муниципального района [4].

Вопрос объединения сельских поселений снова возник в 2019 году. Согласно областному закону Ленинградской области от 07.05.2019 № 35-о3 «Об объединении муниципальных образований в Волосовском муниципальном районе Ленинградской области и о внесении изменений в отдельные областные законы», в Волосовском районе произошло объединение 14 сельских поселений. В результате объединения количество муниципальных образований сократилось с 16 до 7 (рис. 3) [3].

Муниципальные образования приступили к работе в новом формате с 01.01.2020 года. Проведем анализ эффективности работы объединенных муниципалитетов, рассмотрим, как преобразования отразились на местных жителях, какие проблемы существуют после нововведений. Раньше люди приходили к главе поселения по всем волнующим вопросам, оформляли справки, писали заявления, обращения. После преобразований глав сельских поселений осталось всего шесть. Для удобства граждан на местах бывших сельских администраций было принято решение организовать прием граждан по графику. Следует отметить, что для населения важно, насколько быстро власть реагирует на проблемы и своевременно в привычном для граждан режиме их решает, вне зависимости от местонахождения. Люди неоднозначно реагировали на процесс объединение, но негативных перемен не почувствовали.

Объединение позволило решить проблему нехватки кадров и повысить заработную плату квалифицированным специалистам. Сократились расходы на содержание управленческого аппарата. В таблице 1 представлен анализ расходов на содержание органов местного самоуправления (МСУ) Волосовского муниципального района за 2019-2020 гг.

Анализ расходов 2020 года показал, что расходы на содержание органов МСУ сельских поселений Волосовского муниципального района снизились на 15650 тыс. руб.

Углубленный анализ расходов на содержание органов местного самоуправления поселений Волосовского муниципального района представлен в таблице 2.

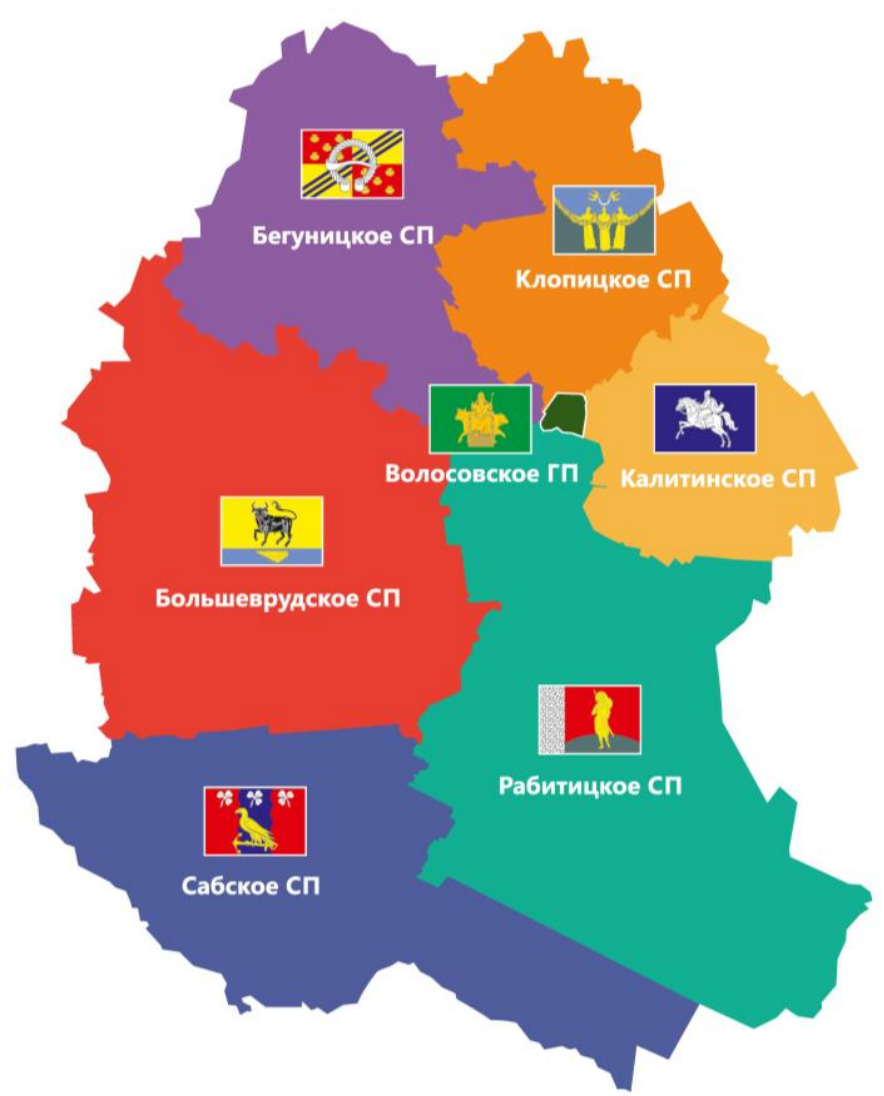

Рисунок 3. Поселения Волосовского муниципального района с 01.01.2020 года [6] 
Таблица 1. Анализ расходов на содержание органов местного самоуправления за 2019-2020 года, тыс. руб. [составлена авторами]

\begin{tabular}{|c|c|c|c|}
\hline \multirow{2}{*}{ Орган МСу } & \multicolumn{2}{|c|}{ Расходы на содержание органов МСУ (тыс. руб.) } & \multirow{2}{*}{ Отклонение } \\
\cline { 2 - 3 } & 2019 год & 2020 год & $-15650,0$ \\
\hline Сельские поселения & 98115,5 & 82465,5 & \\
\hline
\end{tabular}

Таблица 2. Углубленный анализ расходов на содержание сельских поселений 2019-2020 года, тыс. руб. [составлена авторами]

\begin{tabular}{|c|c|c|c|c|}
\hline $\begin{array}{c}\text { Органы МСУ до объеди- } \\
\text { нения }\end{array}$ & $\begin{array}{c}\text { Расходы на содер- } \\
\text { жание органов } \\
\text { МСу 2019 год } \\
\text { (тыс. руб.) }\end{array}$ & $\begin{array}{c}\text { Органы МСУ после } \\
\text { объединения }\end{array}$ & $\begin{array}{c}\text { Расходы на содер- } \\
\text { жание органов } \\
\text { МСУ } 2020 \text { год } \\
\text { (тыс. руб.) }\end{array}$ & Отклонение \\
\hline 1 & 2 & 3 & 4 & 5 \\
\hline Бегуницкое СП & 10397,1 & \multirow{3}{*}{ Бегуницкое СП } & \multirow{3}{*}{13756,0} & \multirow{3}{*}{$-6626,1$} \\
\hline Зимитицкое СП & 5658,7 & & & \\
\hline Терпилицкое СП & 4326,3 & & & \\
\hline Большеврудское СП & 8709,0 & \multirow{4}{*}{$\begin{array}{l}\text { Большеврудское } \\
\text { СП }\end{array}$} & \multirow{4}{*}{19266,5} & \multirow{4}{*}{$-5718,9$} \\
\hline Курское СП & 6201,2 & & & \\
\hline Беседское СП & 4780,4 & & & \\
\hline Каложицкое СП & 5294,8 & & & \\
\hline Калитинское СП & 9089,9 & \multirow{2}{*}{ Калитинское СП } & \multirow{2}{*}{12610,1} & \multirow{2}{*}{$-1961,4$} \\
\hline Кикеринское СП & 5481,6 & & & \\
\hline Клопицкое СП & 5762,6 & \multirow{3}{*}{ Клопицкое СП } & \multirow{3}{*}{16381,8} & \multirow{3}{*}{$-3718,7$} \\
\hline Губаницкое СП & 7346,2 & & & \\
\hline Сельцовское СП & 6991,7 & & & \\
\hline Рабитицкое СП & 4934,9 & \multirow{2}{*}{ Рабитицкое СП } & \multirow{2}{*}{13187,4} & \multirow{2}{*}{$+620,3$} \\
\hline Изварское СП & 7632,2 & & & \\
\hline Сабское СП & 5508,9 & Сабское СП & 7263,70 & $+1754,8$ \\
\hline
\end{tabular}

Углубленный анализ установил, что снижение расходов произошло не во всех сельских поселениях. При общем снижении расходов на содержание сельских поселений, расходы на содержание администрации объединенного $\mathrm{Pa}$ битицкого сельского поселения и Сабского сельского поселения, которое не затронуло объединение, возросли на 2375,1 тыс. руб.

Снижение общих расходов позволило сельским поселениям стать более самостоятельными и уменьшить расходы бюджета Волосовского муниципального района (табл. 3).

В сельских поселениях Волосовского района изменилась численность штатных единиц, приведенная в таблице 4.

Фактическая численность штатных единиц в сельских поселениях Волосовского муниципального района увеличилась на 2,5 штатные единицы.

Углубленный анализ позволил сделать вывод о том, что при общем увеличении штатная численность объединенных Бегуницкого и Боль- шеврудского сельских поселений уменьшилась на 4. Данные об изменении численности органов местного самоуправления по поселениям Волосовского муниципального района представлены в таблице 5.

Эффективность реформы объединения органов местного самоуправления можно анализировать по уровню удовлетворенности граждан работой органов местного самоуправления и по собираемости налоговых доходов в бюджет. Объективно оценить показатель поступления налоговых доходов в бюджеты сельских поселений не представляется возможным ввиду сложившейся эпидемиологической обстановки в 2020 году.

Анализ доходов сельских поселений за 20192020 года приведен в таблицах 6-8.

Установлен рост доходов сельских поселений за счет дотации на выравнивание бюджетной обеспеченности сельских поселений, при общем уменьшении налоговых доходов. Увеличение налоговых доходов в 2020 году наблюдалось только в Калитинском сельском поселении. 
Таблица 3. Расходы на содержание органов МСУ за счет средств бюджета Волосовского муниципального района 2019-2020 года, тыс. руб. [составлена авторами]

\begin{tabular}{|c|c|c|c|c|}
\hline $\begin{array}{c}\text { Органы МСУ } \\
\text { до объединения }\end{array}$ & $\begin{array}{c}\text { Расходы на со- } \\
\text { держание орга- } \\
\text { нов МСу за счет } \\
\text { средств бюджета } \\
\text { Волосовского } \\
\text { муниципального } \\
\text { района } \\
2019 \text { год (тыс. руб.) }\end{array}$ & $\begin{array}{c}\text { Органы МСУ после } \\
\text { объединения }\end{array}$ & $\begin{array}{c}\text { Расходы на со- } \\
\text { держание орга- } \\
\text { нов МСУ за счет } \\
\text { средств бюджета } \\
\text { Волосовского } \\
\text { муниципального } \\
\text { района } \\
2020 \text { год (тыс. руб.) }\end{array}$ & Отклонение \\
\hline Бегуницкое СП & 0 & \multirow{3}{*}{ Бегуницкое СП } & \multirow{3}{*}{0} & \multirow{3}{*}{$-117,2$} \\
\hline Зимитицкое СП & 0 & & & \\
\hline Терпилицкое СП & 117,2 & & & \\
\hline Большеврудское СП & 0 & \multirow{4}{*}{$\begin{array}{c}\text { Большеврудское } \\
\text { СП }\end{array}$} & \multirow{4}{*}{300,0} & \multirow{4}{*}{$-354,7$} \\
\hline Курское СП & 0 & & & \\
\hline Беседское СП & 654,7 & & & \\
\hline Каложицкое СП & 0 & & & \\
\hline Клопицкое СП & 300,0 & \multirow{3}{*}{ Клопицкое СП } & \multirow{3}{*}{0} & \multirow{3}{*}{$-300,0$} \\
\hline Губаницкое СП & 0 & & & \\
\hline Сельцовское СП & 0 & & & \\
\hline Рабитицкое СП & 393,2 & \multirow{2}{*}{ Рабитицкое СП } & \multirow{2}{*}{0} & \multirow{2}{*}{$-393,2$} \\
\hline Изварское СП & 0 & & & \\
\hline Сабское СП & 1130,2 & Сабское СП & 1006,1 & $-124,1$ \\
\hline
\end{tabular}

Таблица 4. Фактическая штатная численность органов местного самоуправления в 2019-2020 гг., чел. [составлена авторами]

\begin{tabular}{|c|c|c|c|}
\hline \multirow{2}{*}{ Орган Мсу } & \multicolumn{2}{|c|}{$\begin{array}{c}\text { Фактическая численность } \\
\text { штатных единиц (чел.) }\end{array}$} & \multirow{2}{*}{ Отклонение } \\
\cline { 2 - 3 } & 2019 года & 2020 года & $+2,5$ \\
\hline Сельские поселения & 90,8 & 93,3 & \\
\hline
\end{tabular}

Таблица 5. Углубленный анализ штатной численности администраций сельских поселений Волосовского муниципального района с 2019-2020 года, чел. [составлена авторами]

\begin{tabular}{|c|c|c|c|c|}
\hline $\begin{array}{c}\text { Органы МСУ } \\
\text { до объединения }\end{array}$ & $\begin{array}{c}\text { Фактическая чис- } \\
\text { ленность штатных } \\
\text { единиц } 2019 \text { год } \\
\text { (чел.) }\end{array}$ & $\begin{array}{c}\text { Органы МСУ после } \\
\text { объединения }\end{array}$ & $\begin{array}{c}\text { Фактическая чис- } \\
\text { ленность штатных } \\
\text { единиц } 2020 \text { год } \\
\text { (чел.) }\end{array}$ & Отклонение \\
\hline 1 & 2 & 3 & 4 & 5 \\
\hline Бегуницкое СП & 6 & \multirow{3}{*}{ Бегуницкое СП } & \multirow{3}{*}{14,5} & \multirow{3}{*}{-3} \\
\hline Зимитицкое СП & 6 & & & \\
\hline Терпилицкое СП & 5,5 & & & \\
\hline Большеврудское СП & 8 & \multirow{4}{*}{ Большеврудское СП } & \multirow{4}{*}{22} & \multirow{4}{*}{-1} \\
\hline Курское СП & 6 & & & \\
\hline Беседское СП & 5 & & & \\
\hline Каложицкое СП & 4 & & & \\
\hline Калитинское СП & 7 & \multirow{2}{*}{ Калитинское СП } & \multirow{2}{*}{15} & \multirow{2}{*}{+1} \\
\hline Кикеринское СП & 7 & & & \\
\hline Клопицкое СП & 6 & \multirow{3}{*}{ Клопицкое СП } & \multirow{3}{*}{20,3} & \multirow{3}{*}{$+2,3$} \\
\hline Губаницкое СП & 6 & & & \\
\hline Сельцовское СП & 6 & & & \\
\hline Рабитицкое СП & 6 & \multirow{2}{*}{ Рабитицкое СП } & \multirow{2}{*}{14} & \multirow{2}{*}{$+1,7$} \\
\hline Изварское СП & 6,3 & & & \\
\hline Сабское СП & 6 & Сабское СП & 7,5 & $+1,5$ \\
\hline
\end{tabular}


Таблица 6. Детальный анализ доходов сельских поселений 2019-2020 года, тыс. руб. [составлена авторами]

\begin{tabular}{|c|c|c|c|c|}
\hline $\begin{array}{c}\text { Органы МСУ } \\
\text { до объединения }\end{array}$ & $\begin{array}{c}\text { Доходы органов } \\
\text { МСУ } 2019 \text { год } \\
\text { (тыс. руб.) }\end{array}$ & $\begin{array}{c}\text { Органы МСУ после } \\
\text { объединения }\end{array}$ & $\begin{array}{c}\text { Доходы органов } \\
\text { МСУ } 2020 \text { год } \\
\text { (тыс. руб.) }\end{array}$ & Отклонениє \\
\hline 1 & 2 & 3 & 4 & 5 \\
\hline Бегуницкое СП & 26707,8 & \multirow{3}{*}{ Бегуницкое СП } & \multirow{3}{*}{53110,9} & \multirow{3}{*}{$+3155,1$} \\
\hline Зимитицкое СП & 13353,2 & & & \\
\hline Терпилицкое СП & 9894,8 & & & \\
\hline Большеврудское СП & 22169,5 & \multirow{4}{*}{ Большеврудское СП } & \multirow{4}{*}{60833,5} & \multirow{4}{*}{$+5030,1$} \\
\hline Курское СП & 13924,5 & & & \\
\hline Беседское СП & 7986,5 & & & \\
\hline Каложицкое СП & 11722,9 & & & \\
\hline Калитинское СП & 21419,7 & \multirow{2}{*}{ Калитинское СП } & \multirow{2}{*}{41639,4} & \multirow{2}{*}{+5683} \\
\hline Кикеринское СП & 14536,7 & & & \\
\hline Клопицкое СП & 10616,5 & \multirow{3}{*}{ Клопицкое СП } & \multirow{3}{*}{51868,8} & \multirow{3}{*}{$+4788,0$} \\
\hline Губаницкое СП & 20841,4 & & & \\
\hline Сельцовское СП & 15622,9 & & & \\
\hline Рабитицкое СП & 10304,4 & \multirow{2}{*}{ Рабитицкое СП } & \multirow{2}{*}{31699,9} & \multirow{2}{*}{$+3062,3$} \\
\hline Изварское СП & 18333,2 & & & \\
\hline Сабское СП & 11209,4 & Сабское СП & 13056,8 & $+1847,4$ \\
\hline Итого & 228643,4 & & 252209,3 & $+23565,9$ \\
\hline
\end{tabular}

Таблица 7. Анализ налоговых доходов сельских поселений за 2019-2020 года, тыс.руб. [составлена авторами]

\begin{tabular}{|c|c|c|c|}
\hline \multirow{2}{*}{ Орган Мсу } & \multicolumn{2}{|c|}{ Налоговые доходы сельских поселений (тыс. руб.) } & \multirow{2}{*}{ Отклонение } \\
\cline { 1 - 3 } & 2019 год & 2020 год & $-1475,8$ \\
\hline Сельские поселения & 108340,6 & 106864,8 & \multirow{2}{*}{} \\
\hline
\end{tabular}

Таблица 8. Детальный анализ налоговых доходов сельских поселений 2019-2020 года, тыс.руб. [составлена авторами]

\begin{tabular}{|c|c|c|c|c|}
\hline $\begin{array}{c}\text { Органы МСУ до объе- } \\
\text { динения }\end{array}$ & $\begin{array}{c}\text { Налоговые доходы } \\
\text { органов МСУ } 2019 \\
\text { год (тыс. руб.) }\end{array}$ & $\begin{array}{c}\text { Органы МСУ после } \\
\text { объединения }\end{array}$ & $\begin{array}{c}\text { Налоговые доходы } \\
\text { органов МСУ } 2020 \\
\text { год (тыс. руб.) }\end{array}$ & Отклонение \\
\hline 1 & 2 & 3 & 4 & 5 \\
\hline Бегуницкое СП & 13141,8 & \multirow{3}{*}{ Бегуницкое СП } & \multirow{3}{*}{25262,2} & \multirow{3}{*}{$-2050,5$} \\
\hline Зимитицкое СП & 9806,4 & & & \\
\hline Терпилицкое СП & 4364,5 & & & \\
\hline Большеврудское СП & 9254,6 & \multirow{4}{*}{ Большеврудское СП } & \multirow{4}{*}{23070,2} & \multirow{4}{*}{$-168,4$} \\
\hline Курское СП & 4266,4 & & & \\
\hline Беседское СП & 2535,3 & & & \\
\hline Каложицкое СП & 7182,3 & & & \\
\hline Калитинское СП & 8504,5 & \multirow{2}{*}{ Калитинское СП } & \multirow{2}{*}{20841,5} & \multirow{2}{*}{$+1360,4$} \\
\hline Кикеринское СП & 10976,6 & & & \\
\hline Клопицкое СП & 5628,0 & \multirow{3}{*}{ Клопицкое СП } & \multirow{3}{*}{23144,5} & \multirow{3}{*}{$-269,5$} \\
\hline Губаницкое СП & 8315,1 & & & \\
\hline Сельцовское СП & 9470,9 & & & \\
\hline Рабитицкое СП & 6311,5 & \multirow{2}{*}{ Рабитицкое СП } & \multirow{2}{*}{10838,3} & \multirow{2}{*}{$-257,3$} \\
\hline Изварское СП & 4784,1 & & & \\
\hline Сабское СП & 3798,6 & Сабское СП & 3708,1 & $-90,5$ \\
\hline
\end{tabular}


По показателям эффективности деятельности органов местного самоуправления Волосовский район на протяжении нескольких лет подряд занимает лидирующие позиции среди районов Ленинградской области. По итогам 2019 года Волосовский район занял 2-е место. Удовлетворенность населения деятельностью Волосовского муниципального района в 2019 году составила 0,5788 процентов от числа опрошенных. Всего в опросе принимало участие 467 человек [5].

Согласно докладу главы администрации муниципального образования Волосовский муниципальный район Ленинградской области «Об итогах социально-экономического развития Волосовского муниципального района в 2020 году и задачах на 2021 год», показатели эффективности деятельности органов местного самоуправления Волосовского района находятся на прежнем уровне.

В целом, проведенный анализ отчётных данных официальных сайтов Ленинградской области, Волосовского муниципального района и сельских поселений района позволяет сделать вывод об экономической эффективности объединения сельских поселений Волосовского района. Однако, считаем, что уровень удовлетворенности граждан работой органов местного самоуправления необходимо изучить более глубоко. Выборка в 467 человек в данном случае, на наш взгляд, не является полностью репрезентативной. Необходимо провести социологический опрос именно жителей объединенных сельских поселений с целью изучения вопроса шаговой доступности местной власти для оперативного решения проблем граждан.

В заключение отметим, что к любым территориальным преобразованиям муниципальных образований необходимо подходить максимально взвешенно, руководствуясь имеющимся практическим опытом субъектов РФ и с учётом мнения жителей. Приведение всех, например, объединенных сельских поселений к средним показателям социально-экономического развития, на наш взгляд, не должно становиться целью территориальной реформы местного самоуправления. Главное в данном случае - это качество жизни населения и возможность граждан взаимодействовать с органами местного самоуправления для решения возникающих проблем.

\section{Библиографический список}

1. Конституция Российской Федерации от 12.12.1993 г. (принята всенародным голосованием 12.12.1993) (с учётом поправок, внесенных Законами РФ о поправках к Конституции РФ от 30.12.2008 N 6-ФКЗ, от 30.12.2008 N 7-ФКЗ, от 05.02.2014 N 2-ФКЗ, от 21.07.2014 N 11-ФК3, от 14.03.2020 N 1-ФКЗ) // Официальный интернет-портал правовой информации www.pravo.gov.ru, 04.07.2020, N 0001202007040001.

2. «Об общих принципах организации местного самоуправления в Российской Федерации». Федеральный закон от 06.10.2003 № 131-ФЗ (в ред. от 01.07.2021) // Собрание законодательства Российской Федерации, N 40, 06.10.2003, ст.3822

3. «Об объединении муниципальных образований в Волосовском муниципальном районе Ленинградской области и о внесении изменений в отдельные областные законы». Закон Ленинградской области от 07.05.2019 № 35-оз // Официальный сайт Администрации Ленинградской области www.lenobl.ru, 08.05.2019.

4. «О наделении соответствующим статусом муниципального образования Волосовский муниципальный район и муниципальных образований в его составе». Закон Ленинградской области от 24.09.2004 № 64-о3 // Вестник Правительства Ленинградской области, N 30, 05.10.2004.

5. «Об утверждении сводного доклада Ленинградской области о результатах мониторинга эффективности деятельности органов местного самоуправления муниципальных районов и городского округа за 2019год». Распоряжение Правительства Ленинградской области от 31.08.2020 г. № 613-p // https://lenobl.ru/media/ content/docs/7548/2019.pdf.

6. Официальный сайт Волосовского муниципального района [Электронный ресурc]. URL: http://волосовскийрайон.рф/ (дата обращения: 05.09.2021).

7. Официальный сайт Бегуницкого сельского поселения [Электронный ресурс]. URL: http://begunici.ru/ (дата обращения: 05.09.2021).

8. Официальный сайт Большеврудского сельского поселения [Электронный ресурс]. URL: http://mobsp.ru/ (дата обращения: 05.09.2021).

9. Официальный сайт Калитинского сельского поселения [Электронный ресурс]. URL: http://калитинское.pф/ (дата обращения: 05.09.2021). 
10. Официальный сайт Клопицкого сельского поселения [Электронный ресурс]. URL: https://klopici.ru/ (дата обращения: 05.09.2021).

11. Официальный сайт Рабитицкого сельского поселения [Электронный ресурc]. URL: http://admrabit.ru/ (дата обращения: 05.09.2021).

12. Официальный сайт Сабского сельского поселения [Электронный ресурс]. URL: http://www.sabsk.ru/page. php?19 (дата обращения: 05.09.2021). 